\title{
窒化リチウムを用いた $\mathrm{LiGaO}_{2}$ の低温合成
}

\author{
馬淵 彰·岩瀬悠里子·杉浦 隆·箕浦秀樹 \\ 岐阜大学大学院工学研究科環境エネルギーシステム専攻, 501-1193 岐阜市柳戸 1-1
}

\section{Low Temperature Synthesis of $\mathrm{LiGaO}_{2}$ Using Lithium Nitride}

\author{
Akira MABUCHI, Yuriko IWASE, Takashi SUGIURA and Hideki MINOURA \\ Environmental and Renewable Energy System Division, Graduate School of Engineering, Gifu University, 1-1, Yanagido, Gifu-shi $501-1193$
}

\begin{abstract}
A novel synthetic route to the preparation of lithium metagallate $\left(\mathrm{LiGaO} \mathrm{O}_{2}\right)$ crystals from $\mathrm{Ga}_{2} \mathrm{O}_{3}$ and $\mathrm{Li}_{3} \mathrm{~N}$ under condition milder than conventional methods has been explored. We have found that a reaction of $\mathrm{Ga}_{2} \mathrm{O}_{3}$ and $\mathrm{Li}_{3} \mathrm{~N}$ at temperatures ranging from $500^{\circ} \mathrm{C}$ and $800^{\circ} \mathrm{C}$ in chloride fluxes yields formation of $\mathrm{LiGaO}_{2}$ single crystals. This technique has applicability to the synthesis of $\mathrm{LiGaO}_{2}$ crystals, which are known to be suitable substrates for epitaxial growth of GaN.

[Received December 8, 2004; Accepted February 17, 2005]
\end{abstract}

Key-words : $\mathrm{LiGaO}_{2}, \mathrm{Li}_{3} \mathrm{~N}, \mathrm{Ga}_{2} \mathrm{O}_{3}$, Chloride flux, Morphlogy, TEM

\section{1. 緒 言}

$\mathrm{LiGaO}_{2}$ はウルツ鉱型複合酸化物であり，斜方晶系に属し透 明でモース硬度 7.5 , 化学的に安定な化合物である. その単結 晶は誘電率が低く, 電気機械結合定数の高い材料であることが 知られ(1)，Marezioによってその結晶構造が明らかにされてい る2)。また $\mathrm{LiGaO}_{2}$ は非線形光学特性をもつことから最初レー ザー用材料として研究が始まった ${ }^{3)}$ が，その後は下火となって いった.

ところが，最近 $\mathrm{GaN}$ 系半導体が青色発光ダイオードやレー ザーダイオード用材料として実用化されるにつれて，その結晶 成長用基板として新たな注目が集むり，研究が活発化してきて (る ${ }^{4) \sim 8)}$. GaN は従来, サファイア基板上にヘテロエピタキ シャル成長により作製されているが，その場合にはサファイア と $\mathrm{GaN}$ との間に $16 \%{ }^{9)}$ という格子不整合を有し，これに起因し て多くの欠陥が存在する問題がある。この格子不整合を緩和す るために，AlNや GaN を低温バッファー層としてサファイア 基板上に設ける技術が開発されて改善が図られた．GaNの結 晶性は大幅に改善され ${ }^{10), 11)}$, これらに伴い電気的, 光学的特性 が向上した.

しかし，こうして得られる $\mathrm{GaN}$ 薄膜も転位密度は $2 \times 10^{10}$ $\mathrm{cm}^{-2}$ 12) となお高いため, サファイアに代わる基板の探索が行わ れてきた。これら候補材料中で， $\mathrm{LiGaO}_{2}$ は $\mathrm{GaN}$ との格子不整 合が $1 \sim 2 \%{ }^{9)}$ ときわめて小さいところから， $\mathrm{GaN}$ の結晶成長用 基板として最近注目されるようになってきた。

$\mathrm{LiGaO}_{2}$ 単結晶の作製は, $\mathrm{LiGaO}_{2}$ 種結晶を $\mathrm{LiOH} と \mathrm{Ga}_{2} \mathrm{O}_{3}$ の $\mathrm{NaOH}$ 溶解液を満たしたオートクレーブ中に置いて結晶 成長を行う水熱法, $\mathrm{LiGaO}_{2}$ を原料に用いるフラックス法や Czochralski 法があり，Remeika らによってそれぞれ報告され ている1).

水熱法は $350^{\circ} \mathrm{C}$ とう比較的低い反応温度で合成できる特徵 を有するが，約 $80 \mathrm{MPa}$ という高圧を必要とするため，これに 耐える圧力容器が必要となる。 しかも反応時間が $2 \sim 10$ 日 と長 (13),14)。フラックス法は， $\mathrm{PbO}-\mathrm{B}_{2} \mathrm{O}_{3}$ などのフラックスを用い て結晶拡大をはかる方法であり，フラックスの除去が必要なう え, $\mathrm{LiGaO}_{2}$ 結晶中に $\mathrm{PbO}$ が混入する問題がある ${ }^{15)}$.

Czochralski 法は, 多結晶 $\mathrm{LiGaO}_{2}$ を原料とする融液から $\mathrm{LiGaO}_{2}$ 種結晶を核として大面積 $\mathrm{LiGaO}_{2}$ 単結晶を成長させる
方法である。 $\mathrm{LiGaO}_{2}$ は $1600^{\circ} \mathrm{C}$ においてコングルエント組成 (congruent melting) を形成するため, $\mathrm{LiGaO}_{2}$ メルトから直接 大きな単結晶の成長ができる。得られた単結晶から $\mathrm{LiGaO}_{2}$ 単結晶ウエハーを切り出し，その上へ電子線エピタキシ法 (MBE) などにより作製した $\mathrm{GaN}$ の特性が報告されている ${ }^{16)}$. Czochralski 法は，大面積基板が作製できる利点を有するが， 成長温度が $1500 \sim 1600^{\circ} \mathrm{C}$ と非常に高いため, $\mathrm{Li}_{2} \mathrm{O}$ が揮発し融 液組成が変化する欠点がある.

ここで, $\mathrm{LiGaO}_{2}$ 単結晶の作製に関する従来の手法をまとめ ると, 水熱法, フラックス法, Czochralski 法ではいずれも原 料となる $\mathrm{LiGaO}_{2}$ を合成したのち，これらを原料として結晶成 長を行う. $\mathrm{LiGaO}_{2}$ の合成については, Tate と Oishi は $\mathrm{Li}_{2} \mathrm{CO}_{3}$ と $\mathrm{Ga}_{2} \mathrm{O}_{3}$ とをモル比 $1: 1$ で $900^{\circ} \mathrm{C}, 3 \mathrm{~h}$ 固体反応させ ${ }^{15)}$, Ishii ら は $\mathrm{Li}_{2} \mathrm{CO}_{3}$ と $\mathrm{Ga}_{2} \mathrm{O}_{3}$ t $1300^{\circ} \mathrm{C}, 20 \mathrm{~h}$ 空気中で反応させており ${ }^{16)}$ いずれも高温が必要である。

著者らは環境負荷の低い $\mathrm{GaN}$ 合成法に関する検討の中で， フラックスとして $\mathrm{LiCl}, \mathrm{KCl}, \mathrm{NaCl}$ を用い, $\mathrm{Ga}_{2} \mathrm{O}_{3}$ と $\mathrm{Li}_{3} \mathrm{~N}$ とを 反応させると，比較的低温で $\mathrm{LiGaO}_{2}$ が生成することを見出し た。そして, 従来の合成法と比べると格段に温和な反応条件下 で $\mathrm{LiGaO}_{2}$ が合成できる点に着目した．これに基づいて，直接 大面積で高品質の $\mathrm{LiGaO}_{2}$ 単結晶育成への手順の検討を開始し た。本研究では，それに先立って，上記のフラックス中におけ る反応温度, モル比等の反応条件と得られる生成物の関係を検 討することを目的とした

\section{2. 実験方法}

$\mathrm{LiGaO}_{2}$ 合成のための出発物質として $\mathrm{Ga}_{2} \mathrm{O}_{3}$ (キシダ化学, 純度 $99.99 \%$ ）と $\mathrm{Li}_{3} \mathrm{~N}$ （アルドリッチ，純度不明）を用いた。 本研究では反応媒質として塩化物系フラックスを用いたが, 種々の温度での実験を可能にするために, 融点を考慮してフ ラックスの組成を表 1 のように選択した。すなわち, 反応中の フラックスの揮発を極力防ぐため, 反応はフラックスの融点よ

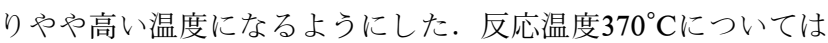
反応温度の下限を探るため, 反応温度 $450^{\circ} \mathrm{C}$ と同じフラックス 組成に設定した。な拉，用いたフラックスは $\mathrm{LiCl}$ (キシダ化 学, 純度 $99.9 \%$ ), $\mathrm{KCl}$ (ナカライテスク, 純度 $99.5 \%$ ), $\mathrm{NaCl}$ （キシダ化学, 純度 $99.5 \%$ ) である. 
Table 1. Composition of the Fluxes Used

\begin{tabular}{|c|c|c|c|c|}
\hline Reaction & Melting & LiCl & K C $1 ~$ & NaCl \\
Temperature & poit & $(\mathrm{mmol})$ & $(\mathrm{mmol})$ & $(\mathrm{mmol})$ \\
\hline 370 & 405 & 41 & 29 & \\
\hline 450 & 405 & 41 & 29 & \\
\hline 550 & 510 & 20 & 47 & \\
\hline 600 & 550 & 42 & 24 & \\
\hline 700 & 685 & & 33 & 33 \\
\hline 800 & 730 & & 51 & 15 \\
\hline
\end{tabular}

乾燥窒素を充填したグローブボックス中で, $\mathrm{Ga}_{2} \mathrm{O}_{3}$ と $\mathrm{Li}_{3} \mathrm{~N}$ を $\mathrm{SiO}_{2} 63 \%, \mathrm{Al}_{2} \mathrm{O}_{3} 31 \%$ よりなる外径 $\phi 36 \mathrm{~mm}$, 高さ $27 \mathrm{~mm}$, 容量 $15 \mathrm{ml}$ のフタなしるつぼ中にフラックスとともに秤量しよ く混合した.

石英ガラス管中にるつぼを収納したあと密閉し，電気炉に セットした．次に流量 $150 \mathrm{ml} / \mathrm{min}$ の窒素（純度 $99.9995 \%$ ）を 通しながら $370 \sim 800^{\circ} \mathrm{C}$ まて昇温速度 $15^{\circ} \mathrm{C} / \mathrm{min}$ で加熱し, $24 \mathrm{~h}$ 反応させた. 反応終了後, 石英ガラス管を室温まで冷却し, る つぼをとり出した．るつぼに蒸留水を加えフラックスを溶解さ せた後, 沪過により生成物をフラックスの溶解液を沪紙により 分離して, $80^{\circ} \mathrm{C}, 1 \mathrm{~h}$ 乾燥させた.

反応機構の解析のために示差熱分析, 熱重量分析を行った が，それにはDTA-50 (島津製作所製)，TGA-50 (島津製作所 製）をそれぞれ用い，高純度窒素ガス雾囲気中 $(100 \mathrm{ml} / \mathrm{min})$ に 打いて測定した。昇温速度 $5 \sim 20^{\circ} \mathrm{C} / \mathrm{min}$, 測定セルは $\mathrm{Pt}$ 製セ ル $(\phi 5.2 \mathrm{~mm}, \mathrm{H} 5.0 \mathrm{~mm})$ を使用した. 生成物は $\mathrm{Cu} \mathrm{K} \alpha$ 線 $(\lambda=$ $0.154183 \mathrm{~nm}$ ) を用いた X 線粉末回折装置 (理学電機製, RAD2R）により同定した。表面形態の観察は走査型電子顕微鏡 (SEM ; 日立製作所製, S-4300), 結晶構造は透過型電子顕微鏡 （TEM；日立製作所製，H-8100）を用い加速電圧 $200 \mathrm{kV}$ によ りそれぞれ観察した。

\section{3. 結果と考察}

\section{1 反応温度とモル比の影響}

図 1 はフラックス中で $\mathrm{Ga}_{2} \mathrm{O}_{3}$ と $\mathrm{Li}_{3} \mathrm{~N}$ とを $370 \sim 800^{\circ} \mathrm{C}$ の温度 範囲で加熱して得られた生成物の粉末 $\mathrm{X}$ 線回折 (XRD) パター

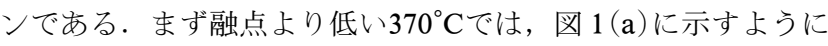
未反応の $\mathrm{Ga}_{2} \mathrm{O}_{3}$ の回折ピークのみが認められ, $\mathrm{Ga}_{2} \mathrm{O}_{3}$ と $\mathrm{Li}_{3} \mathrm{~N}$ との反応は進行しないことが分かる. XRD パターンに $\mathrm{Li}_{3} \mathrm{~N}$ の 回折ピークが認められないのは, 未溶融のフラックスを除去す るため生成物に蒸留水を加えたとき, $\mathrm{Li}_{3} \mathrm{~N}$ と $\mathrm{H}_{2} \mathrm{O}$ の反応によ り $\mathrm{LiOH}$ が生成し, これが水に溶解したためと考えられる.

$450^{\circ} \mathrm{C}$ では図 1 (b)に示すように, 未反応 $\mathrm{Ga}_{2} \mathrm{O}_{3}$ による回折 ピーク以外に $\mathrm{LiGaO}_{2}$ に帰属される回折ピークが現れ, $\mathrm{LiGaO}_{2}$ の生成が認められた.

$550^{\circ} \mathrm{C}$ 以上になると図 $1(\mathrm{c}) \sim(\mathrm{f})$ に示すように，すべての回折 ピークが $\mathrm{LiGaO}_{2}$ に帰属され, JCPDS カードとの比較から斜 方晶 $\mathrm{LiGaO}_{2}$ の形成が確かめられた。

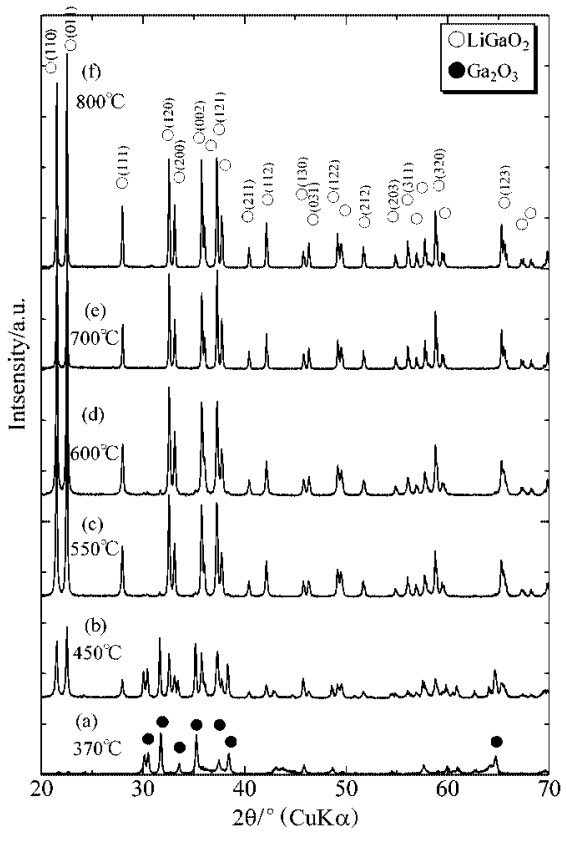

Fig. 1. X-ray powder diffraction patterns of $\mathrm{LiGaO}_{2}$ prepared by a reaction of $\mathrm{Ga}_{2} \mathrm{O}_{3} 2 \mathrm{mmol}$ with $\mathrm{Li}_{3} \mathrm{~N} 4 \mathrm{mmol}$ in fluxes shown in Table 1 at (a) $370^{\circ} \mathrm{C}$, (b) $450^{\circ} \mathrm{C}$, (c) $550^{\circ} \mathrm{C}$, (d) $600^{\circ} \mathrm{C}$, (e) $700^{\circ} \mathrm{C}$, and (f) $800^{\circ} \mathrm{C}$.

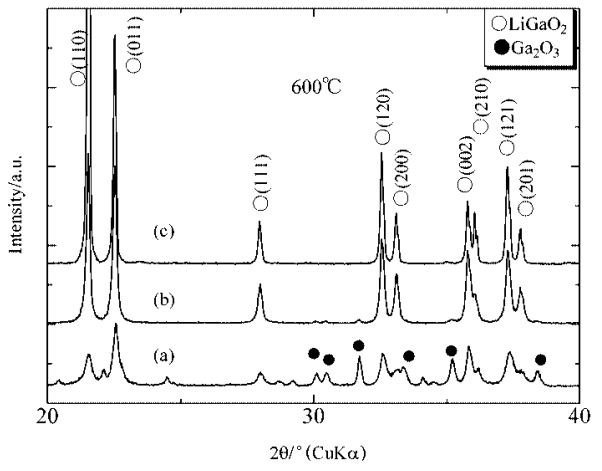

Fig. 2. X-ray powder diffraction patterns of $\mathrm{LiGaO}_{2}$ prepared by a reaction of $\mathrm{Ga}_{2} \mathrm{O}_{3} 2 \mathrm{mmol}$ with $\mathrm{Li}_{3} \mathrm{~N}$ (a) $2 \mathrm{mmol}$, (b) $4 \mathrm{mmol}$ and (c) $9.74 \mathrm{mmol}$ in fluxes shown in Table 1 at $600^{\circ} \mathrm{C}$ for $24 \mathrm{~h}$.

図 2 は $\mathrm{Ga}_{2} \mathrm{O}_{3} / \mathrm{Li}_{3} \mathrm{~N}$ のモル比を変えて得られた生成物の XRD パターンである. $\mathrm{Ga}_{2} \mathrm{O}_{3} / \mathrm{Li}_{3} \mathrm{~N}=2 \mathrm{mmol} / 2 \mathrm{mmol}$ の場合には, 図 2 (a)に示すように, 未反応 $\mathrm{Ga}_{2} \mathrm{O}_{3}$ のピークが認められた. $\mathrm{Li}_{3} \mathrm{~N}$ の量を増やして $\mathrm{Ga}_{2} \mathrm{O}_{3} / \mathrm{Li}_{3} \mathrm{~N}=2 \mathrm{mmol} / 4 \mathrm{mmol}, 2 \mathrm{mmol} /$ $9.74 \mathrm{mmol}$ とすると, 図 $2(\mathrm{~b})$, (c) のように得られた生成物は すべて $\mathrm{LiGaO}_{2}$ となった.

\section{2 熱分析}

本反応系においては, $\mathrm{Li}_{3} \mathrm{~N}$ が重要な役割を果たすことは言 うまでもない。そこで $\mathrm{LiGaO}_{2}$ 形成に至る反応機構を解明する に当たって, 昇温に伴う $\mathrm{Li}_{3} \mathrm{~N}$ 自身の变化についての検討を行 うこととした.

$\mathrm{Li}_{3} \mathrm{~N}$ のみを $\mathrm{Pt}$ セル内にて $700^{\circ} \mathrm{C}$ あで $5^{\circ} \mathrm{C} / \mathrm{min}, 10^{\circ} \mathrm{C} / \mathrm{min}$ の 昇温速度により加熱して得られたDTA曲線と, $800^{\circ} \mathrm{C}$ な゙ $20^{\circ} \mathrm{C} / \mathrm{min}$ の昇温速度により加熱昇温して得られた DTA 曲線 を図 3 に示す。このDTA 曲線によれば, $250^{\circ} \mathrm{C}, 400^{\circ} \mathrm{C}$ に微小 な発熱ピークが認められるものの, $700^{\circ} \mathrm{C}$ な゙は大きな発熱 


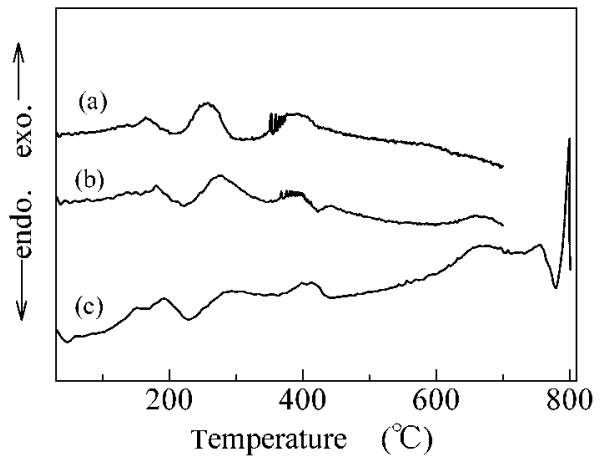

Fig. 3. DTA curves of $\mathrm{Li}_{3} \mathrm{~N}$ in pure nitrogen atmosphere. Heating rate was (a) $5^{\circ} \mathrm{C} / \mathrm{min}$, (b) $10^{\circ} \mathrm{C} / \mathrm{min}$, (c) $20^{\circ} \mathrm{C} / \mathrm{min}$. Weight of samples were $10 \mathrm{mg}$. $\mathrm{N}_{2}$ flow rate was $100 \mathrm{ml} / \mathrm{min}$.

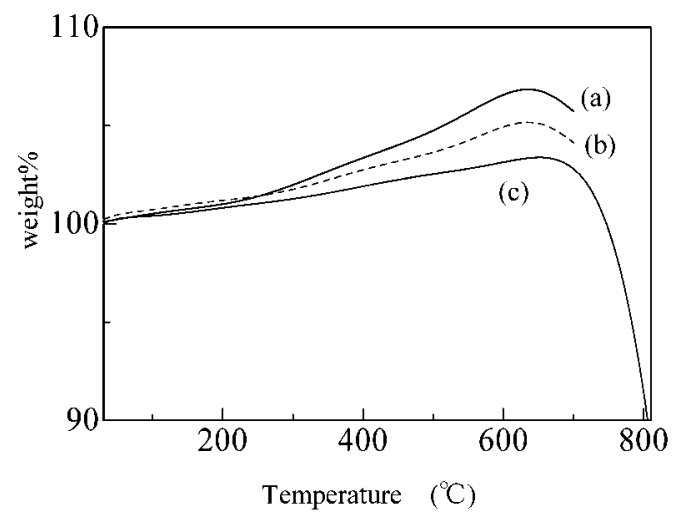

Fig. 4. TG curves of $\mathrm{Li}_{3} \mathrm{~N}$ in pure nitrogen atmosphere. Heating rates were (a) $5^{\circ} \mathrm{C} / \mathrm{min}$, (b) $10^{\circ} \mathrm{C} / \mathrm{min}$, (c) $20^{\circ} \mathrm{C} / \mathrm{min}$. Weight of samples were $10 \mathrm{mg}$. $\mathrm{N}_{2}$ flow rate was $100 \mathrm{ml} / \mathrm{min}$.

ピークは認められない. $800^{\circ} \mathrm{C}$ まで加熱した図 $3(\mathrm{c})$ については $\mathrm{Li}_{3} \mathrm{~N}$ の酸化分解と考えられる発熱ピークが認められた。

図 4 は図 3 と同一条件で $\mathrm{Li}_{3} \mathrm{~N}$ のみを $\mathrm{Pt}$ セル内にて加熱して 得た TG曲線である。いずれも $650^{\circ} \mathrm{C}$ 付近において昇温速度 $5^{\circ} \mathrm{C} / \mathrm{min}$ では $7 \%, 10^{\circ} \mathrm{C} / \mathrm{min}$ では $5 \%, 20^{\circ} \mathrm{C} / \mathrm{min}$ では $3 \%$ の重 量増加が認められた。用いた高純度 $\mathrm{N}_{2}$ に含有される不純物の 積算量は実測值（3～7\%）に対し，1\%に満たないことから， この重量増加の原因は, TG, DTA 装置内に吸着した $\mathrm{H}_{2} \mathrm{O}, \mathrm{O}_{2}$ などがキャリアガスの $\mathrm{N}_{2}$ により運ばれ， $\mathrm{Pt}$ セル内の $\mathrm{Li}_{3} \mathrm{~N}$ と 反応し重量が増加するものと考えられる。

図 4 (c) には $800^{\circ} \mathrm{C} に$ 抢いて $\mathrm{Li}_{3} \mathrm{~N}$ の分解によると考えられる 10\%の重量減少が認められた. 図 4(a), (b)については $700^{\circ} \mathrm{C} て ゙$ 加熱を停止しているが，図 $4(\mathrm{c})$ と同様に $\mathrm{Li}_{3} \mathrm{~N}$ の分解による重 量減少の傾向が認められた.

図 5 は図 3 と同一条件で加熱した後, Pt セル内に残った $\mathrm{Li}_{3} \mathrm{~N}$ の XRD パターンを示したものである. 図 $5(\mathrm{a})$ ，(c)ではブロー ドな回折ピークが認められた。一部の $\mathrm{Li}_{3} \mathrm{~N}$ が分解し $\mathrm{Li}-\mathrm{Li}_{3} \mathrm{~N}$ 共結組成をつくるため $\mathrm{Li}_{3} \mathrm{~N}$ の結晶性が低下するためと考えら れる ${ }^{17)}$. 図 5(b)の XRD パターンには未反応 $\mathrm{Li}_{3} \mathrm{~N}$ の回折ピー クが認められた。この条件では $\mathrm{Li}_{3} \mathrm{~N}$ は比較的安定であると考 えられる。

いずれの XRD パターンからも未反応 $\mathrm{Li}_{3} \mathrm{~N}$ に加えて, $\mathrm{Li}_{2} \mathrm{O}$ に帰属される強い回折ピークと LiOH に帰属される回折ピーク が認められた。図 3 には $\mathrm{Li}_{2} \mathrm{O}$ の生成に対応する発熱ピークは

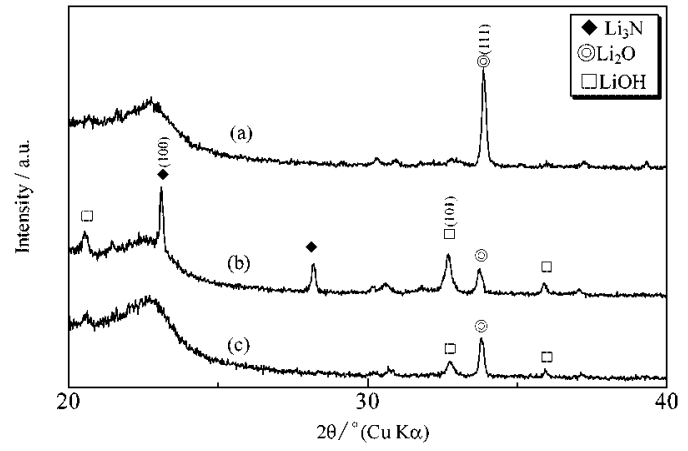

Fig. 5. X-ray powder diffraction patterns of $\mathrm{Li}_{3} \mathrm{~N}$. Heating rates were (a) $5^{\circ} \mathrm{C} / \mathrm{min}$, (b) $10^{\circ} \mathrm{C} / \mathrm{min}$ and (c) $20^{\circ} \mathrm{C} / \mathrm{min}$.

認められない。 $\mathrm{Li}_{3} \mathrm{~N}$ は $\mathrm{H}_{2} \mathrm{O}$ や $\mathrm{O}_{2}$ と反応しやすいことが知ら れている(1).

そこで, $\mathrm{Li}_{2} \mathrm{O}$ が $\mathrm{Li}_{3} \mathrm{~N}$ と $\mathrm{O}_{2}$ の反応により生成すると仮定す ると, 次のように書かれよう.

$4 \mathrm{Li}_{3} \mathrm{~N}+3 \mathrm{O}_{2} \longrightarrow 6 \mathrm{Li}_{2} \mathrm{O}+2 \mathrm{~N}_{2} \uparrow$

また， $\mathrm{Li}_{2} \mathrm{O}$ が $\mathrm{Li}_{3} \mathrm{~N}$ と $\mathrm{H}_{2} \mathrm{O}$ の反応により $\mathrm{LiOH}$ が生成し， 更に脱水され $\mathrm{Li}_{2} \mathrm{O}$ が生成すると仮定すると次のように書かれ よう.

$$
\begin{aligned}
& \mathrm{Li}_{3} \mathrm{~N}+3 \mathrm{H}_{2} \mathrm{O} \longrightarrow 3 \mathrm{LiOH}+\mathrm{NH}_{3} \uparrow \\
& 2 \mathrm{LiOH} \longrightarrow \mathrm{Li}_{2} \mathrm{O}+\mathrm{H}_{2} \mathrm{O}
\end{aligned}
$$

図 5(a)では $\mathrm{Li}_{2} \mathrm{O}$ のみが認められ, 図 5(b), (c)では $\mathrm{LiOH,}$ $\mathrm{Li}_{2} \mathrm{O}$ が認められた. $\mathrm{Li}_{3} \mathrm{~N}$ を長時間 $\mathrm{N}_{2}$ 中で加熱すると（1）式の 反応により $\mathrm{Li}_{2} \mathrm{O}$ が生成し，(2)式の反応により $\mathrm{LiOH}$ が生成す るが最終的には (3) 式の反応により $\mathrm{Li}_{2} \mathrm{O}$ が生成するものと考え られる.

フラックス中に拈いて, $\mathrm{Li}_{3} \mathrm{~N}$ は $\mathrm{H}_{2} \mathrm{O}$ と $\mathrm{O}_{2}$ の どちらと主と して反応するかを調べるため, カールフィッシャー法により $\mathrm{LiCl}, \mathrm{KCl}, \mathrm{NaCl}, \mathrm{Ga}_{2} \mathrm{O}_{3}$ の水分含有率をそれぞれ測定した。 そ の結果によれば， $\mathrm{LiCl}$ の水分含有率は $7.22 \%$ と多く， $\mathrm{KCl}$ のそ れは0.06\%, $\mathrm{NaCl}$ のそれは0.04\%, $\mathrm{Ga}_{2} \mathrm{O}_{3}$ のそれは $0.45 \%$ る ことが分かった.

以上の結果を考慮して, $\mathrm{LiGaO}_{2}$ の生成メカニズムを以下の ように推定した。 まずフラックスや $\mathrm{Ga}_{2} \mathrm{O}_{3}$ に含まれる $\mathrm{H}_{2} \mathrm{O}$ が $\mathrm{Li}_{3} \mathrm{~N}$ と反応して $\mathrm{LiOH}$ が生成し，それが (4) 式に示すように $\mathrm{Ga}_{2} \mathrm{O}_{3}$ と反応して $\mathrm{LiGaO}_{2}$ を与えるものと結論される.

$$
\mathrm{Ga}_{2} \mathrm{O}_{3}+2 \mathrm{LiOH} \longrightarrow 2 \mathrm{LiGaO}_{2}+\mathrm{H}_{2} \mathrm{O}
$$

(4) 式で生成した $\mathrm{H}_{2} \mathrm{O}$ はさらに $\mathrm{Li}_{3} \mathrm{~N}$ と(2)式のように反応し さらに $\mathrm{LiOH}$ を生成するものと考えられる.

また， $\mathrm{Li}_{3} \mathrm{~N}$ と $\mathrm{O}_{2}$ との反応により生成した $\mathrm{Li}_{2} \mathrm{O}$ を $\mathrm{Ga}_{2} \mathrm{O}_{3}$ と (5)式のように反応し $\mathrm{LiGaO}_{2}$ が生成することが考えられる.

$$
\mathrm{Li}_{2} \mathrm{O}+\mathrm{Ga}_{2} \mathrm{O}_{3} \longrightarrow 2 \mathrm{LiGaO}_{2}
$$

そこで, 確認のために $\mathrm{Li}_{2} \mathrm{O} 2 \mathrm{mmol}$ と $\mathrm{Ga}_{2} \mathrm{O}_{3} 2 \mathrm{mmol}$ をフ ラックス中で図 1 (e) と同一の条件で反応させ，生成物の X 線回折による同定を行ったところ, 図 6 に示すように確かに $\mathrm{LiGaO}_{2}$ の生成が認められたものの, 多くの $\mathrm{Ga}_{2} \mathrm{O}_{3}$ が未反応の まま残り， $\mathrm{Li}_{3} \mathrm{~N}$ を用いた場合と異なることが分かった。こ れに関しては，フラックス中でも(4)，(5)式の反応により $\mathrm{LiGaO}_{2}$ が生成するばかりでなく, より活性な $\mathrm{Li}_{3} \mathrm{~N}$ が $\mathrm{Ga}_{2} \mathrm{O}_{3}$ 


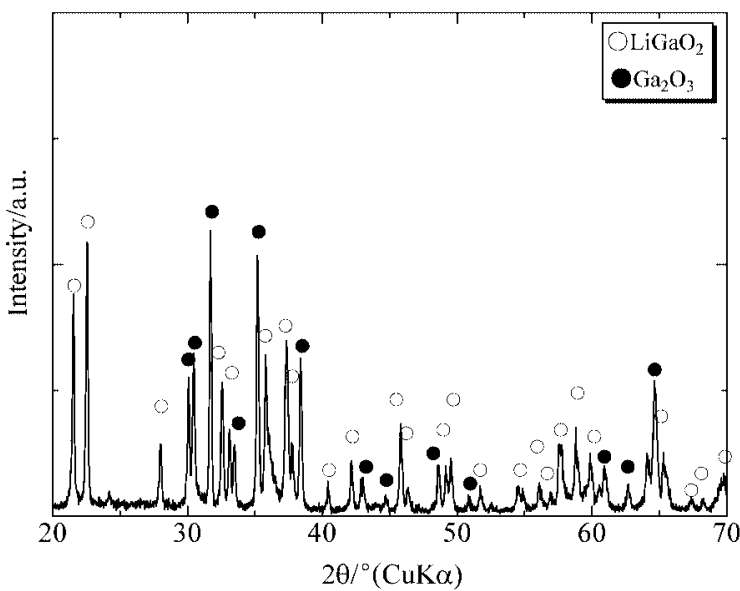

Fig. 6. X-ray powder diffraction patterns of $\mathrm{LiGaO}_{2}$ prepared by a reaction of $\mathrm{Ga}_{2} \mathrm{O}_{3} 2 \mathrm{mmol}$ with $\mathrm{Li}_{2} \mathrm{O} 2 \mathrm{mmol}$ in $\mathrm{NaCl} 33 \mathrm{mmol}, \mathrm{KCl} 33$ $\mathrm{mmol}$ at $700^{\circ} \mathrm{C}$ for $24 \mathrm{~h}$.

Table 2. Lattice Constants and Crystallite Sizes of $\mathrm{LiGaO}_{2}$ Prepared at $450-800^{\circ} \mathrm{C}$

\begin{tabular}{|c|c|c|c|c|}
\hline Temperature $\left({ }^{\circ} \mathrm{C}\right)$ & $\mathrm{a}(\mathrm{nm})$ & $\mathrm{b}(\mathrm{mm})$ & $\mathrm{c}(\mathrm{nm})$ & $\mathrm{D}_{110}(\mathrm{~nm})$ \\
\hline 450 & 0.5416 & 0.6382 & 0.5019 & 40.9 \\
\hline 550 & 0.5419 & 0.6377 & 0.5019 & 46.8 \\
\hline 600 & 0.5411 & 0.6379 & 0.5019 & 45.4 \\
\hline 700 & 0.5408 & 0.6378 & 0.5017 & 58.9 \\
\hline 800 & 0.5414 & 0.6375 & 0.5017 & 59.2 \\
\hline Marezio 21 & 0.5402 & 0.6372 & 0.5007 & $* *$ \\
\hline
\end{tabular}

を還元し，これが有効に $\mathrm{LiGaO}_{2}$ 生成へと導いているものと考 えられる.

著者らは, るつぼを圧力容器に格納し， $\mathrm{H}_{2} \mathrm{O}, \mathrm{O}_{2}$ を減圧によ り除いた後, $\mathrm{N}_{2}$ 加圧下でフラックスを使用せず $\mathrm{Li}_{3} \mathrm{~N}$ と $\mathrm{Ga}_{2} \mathrm{O}_{3}$ を反応させると, $\mathrm{GaN}$ と $\mathrm{Li}_{2} \mathrm{O}$ が生成することを確認してい る ${ }^{19)}$. その反応は (6)式のように書くことができる.

$$
2 \mathrm{Li}_{3} \mathrm{~N}+\mathrm{Ga}_{2} \mathrm{O}_{3} \longrightarrow 2 \mathrm{GaN}+3 \mathrm{Li}_{2} \mathrm{O}
$$

しかし, 微量の $\mathrm{H}_{2} \mathrm{O}$ が存在すると, $\mathrm{GaN}$ に代わって $\mathrm{LiGaO}_{2}$ が生成するが，このように反応条件に打けるわずかな違いに よって生成物の作りわけを可能にする点は興味深い. $\mathrm{H}_{2} \mathrm{O}$ が存 在する場合には, $\mathrm{Ga}_{2} \mathrm{O}_{3}$ の還元が不十分となり, $\mathrm{LiGaO}_{2}$ が生 成するものと推測される。

\section{3 得られた $\mathrm{LiGaO}_{2}$ の格子定数及び結晶子径}

表 2 には $450 \sim 800^{\circ} \mathrm{C}$ で反応させて得られた $\mathrm{LiGaO}_{2}$ の $\mathrm{X}$ 線回 折データより見積もられた格子定数及び結晶子径を示す. 後者 は (110)面からの回折ピークから評価した。これによると，反 応温度を变えてもその格子定数の值は $a=0.5408 \sim 0.5419 \mathrm{~nm}$, $b=0.6375 \sim 0.6382 \mathrm{~nm}, c=0.5017 \sim 0.5019 \mathrm{~nm}$ というきわめて 小さな変化しかなく, Marezioによって求められた $\mathrm{LiGaO}_{2}$ の 格子定数 $a=0.5402 \mathrm{~nm}, b=0.6372 \mathrm{~nm}, c=0.5007 \mathrm{~nm}^{2)}$ とほぼ一 致している．結晶子径は反応温度の上昇とともに大きくなる傾

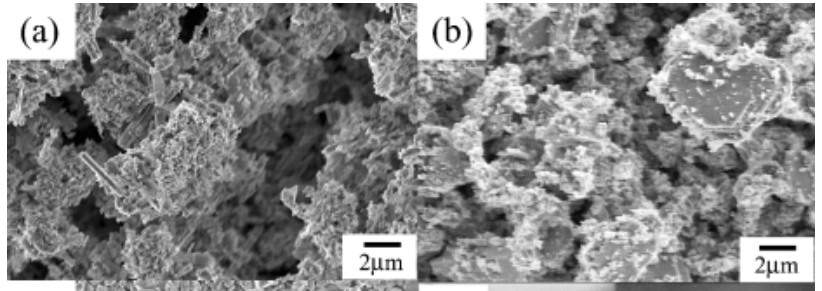

(c)

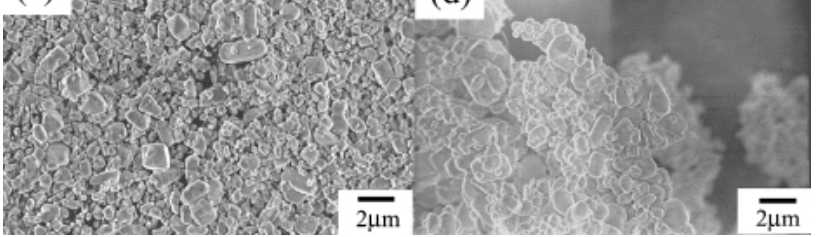

Fig. 7. SEM photographs of $\mathrm{LiGaO}_{2}$ prepared by a reaction of $\mathrm{Ga}_{2} \mathrm{O}_{3} 2 \mathrm{mmol}$ with $\mathrm{Li}_{3} \mathrm{~N} 4 \mathrm{mmol}$ in fluxes shown in Table 1 at (a) $450^{\circ} \mathrm{C}$, (b) $600^{\circ} \mathrm{C}$, (c) $700^{\circ} \mathrm{C}$, and (d) $800^{\circ} \mathrm{C}$ for $24 \mathrm{~h}$.

向を示し， $700 \sim 800^{\circ} \mathrm{C}$ において約 $59 \mathrm{~nm}$ であった。この温度に おいては， $\mathrm{Li}_{3} \mathrm{~N}$ がフラックス中で解離し，これにより生成し た $\mathrm{Li}$ と $\mathrm{Li}_{3} \mathrm{~N}$ とが共晶組成を形成して融体となり ${ }^{17)}$ ，このこと が粒成長を引き起こしているのではないかと推測される.

\subsection{SEM による表面形態観察}

図 7 は $\mathrm{Ga}_{2} \mathrm{O}_{3} / \mathrm{Li}_{3} \mathrm{~N}=2 \mathrm{mmol} / 4 \mathrm{mmol}$ の組成で仕込み, 種々 の温度で反応させて得られた $\mathrm{LiGaO}_{2}$ の SEM 写真である. 450 ${ }^{\circ} \mathrm{C}$ では, 図 7(a)に示すように, 微小な棒状の $\mathrm{LiGaO}_{2}$ 結晶が認 められたが, 結晶はほとんど成長していないことが分かる. $600^{\circ} \mathrm{C}$ では, 微細な $\mathrm{LiGaO}_{2}$ 粒子中に約 $5 \mu \mathrm{m}$ の結晶が認められ た. 更に, 反応温度を $700,800^{\circ} \mathrm{C}$ とした場合には, 図 $7(\mathrm{c}),(\mathrm{d})$ に示すように, 約 $2 \mu \mathrm{m}$ の結晶が認められる. フラックス中で $\mathrm{LiGaO}_{2}$ 結晶が成長することがうかがわれる．結晶の角が取れ ているのは，フラックスを除くためにるつぼ中の生成物に水を 加えるが，その際に $\mathrm{LiGaO}_{2}$ 表面がわずかに溶解したことによ るものではないかと考えている．このことは実際に生成物を沪 過分離した後の沪液の蒸発乾固物から $\mathrm{LiGaO}_{2}$ が検出されたこ とから確かめられた。

次に, モル比を $\mathrm{Ga}_{2} \mathrm{O}_{3} / \mathrm{Li}_{3} \mathrm{~N}=2 \mathrm{mmol} / 2 \mathrm{mmol}$ として各種温 度で $24 \mathrm{~h}$ 反応させた．こうして得られた生成物の SEM 写真を 図 8 (a), (b), (c)に示す。 また, 図 8(d), (e), (f) はモル比を $\mathrm{Ga}_{2} \mathrm{O}_{3} / \mathrm{Li}_{3} \mathrm{~N}=2 \mathrm{mmol} / 9.74 \mathrm{mmol}$ として同様に得られた生成物 の SEM 写真である. モル比が $2 \mathrm{mmol} / 2 \mathrm{mmol}$ の場合, 粒子の 拡大は小さいが，モル比が $2 \mathrm{mmol} / 9.74 \mathrm{mmol}$ の場合 $\mathrm{LiGaO}_{2}$ 粒子が拡大しているように見える。前述したように，この温度 に抢いては過剩に存在する $\mathrm{Li}_{3} \mathrm{~N}$ がフラックス中で解離し，そ の結果生成した $\mathrm{Li}$ と $\mathrm{Li}_{3} \mathrm{~N}$ とが共晶組成を形成するためと考え

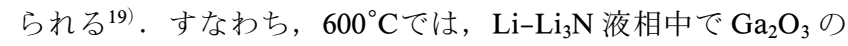
還元が進むため $\mathrm{LiGaO}_{2}$ 粒子の成長が進むものと考えている.

\subsection{TEM による構造観察}

反応により得られた試料をマイクログリッドに搭載し， TEM 観察を抢こなった. 図 9 (a)はその一例であるが，ここに は約 $1 \mu \mathrm{m}$ の大きさの結晶が認められる，それに対応する制限 視野電子線回折像を図 9 (b) に示す。得られた試料はいずれも

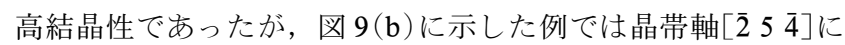
対応しており, $\mathrm{LiGaO}_{2}$ による回折点は図中に示されたように 指数付けされることが分かった. 


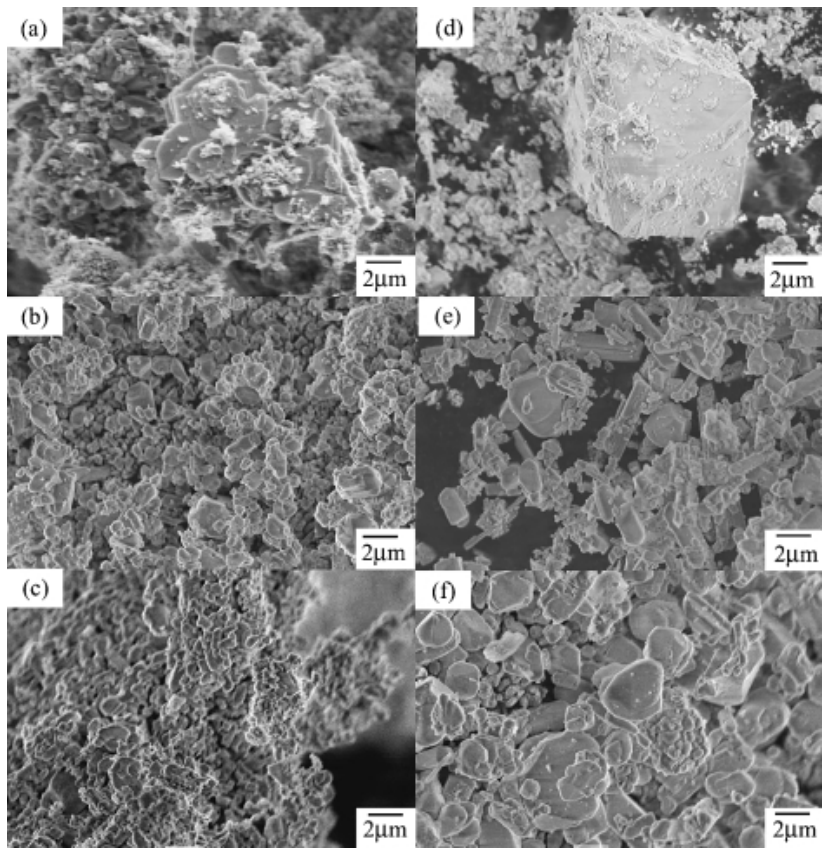

Fig. 8. SEM photographs of $\mathrm{LiGaO}_{2}$ prepared by a reaction of $\mathrm{Ga}_{2} \mathrm{O}_{3} 2 \mathrm{mmol}$ with $\mathrm{Li}_{3} \mathrm{~N} 2 \mathrm{mmol}$ in molten salts at (a) $600^{\circ} \mathrm{C}$, (b) 700 ${ }^{\circ} \mathrm{C}$, (c) $800^{\circ} \mathrm{C}$ for $24 \mathrm{~h}$ and prepared by a reaction of $\mathrm{Ga}_{2} \mathrm{O}_{3} 2 \mathrm{mmol}$ with $\mathrm{Li}_{3} \mathrm{~N} 9.74 \mathrm{mmol}$ in fluxes shown in Table 1 at (d) $600^{\circ} \mathrm{C}$, (e) 700 ${ }^{\circ} \mathrm{C}$, (f) $800^{\circ} \mathrm{C}$ for $24 \mathrm{~h}$.

\section{4. まとめ}

$\mathrm{KCl}-\mathrm{LiCl}-\mathrm{NaCl}$ 系フラックス中で $\mathrm{Ga}_{2} \mathrm{O}_{3}$ と $\mathrm{Li}_{3} \mathrm{~N}$ を反応させ ることにより $\mathrm{LiGaO}_{2}$ 結晶を合成できることが分かった. $\mathrm{Ga}_{2} \mathrm{O}_{3}$ と $\mathrm{Li}_{3} \mathrm{~N}$ のモル比や反応温度を変えても広い範囲で $\mathrm{LiGaO}_{2}$ の 生成が確認されたが，これはわずかに含まれる $\mathrm{H}_{2} \mathrm{O}$ が影響す るものと推測された.すなわち $\mathrm{H}_{2} \mathrm{O}$ が存在する場合には, $\mathrm{Li}_{3} \mathrm{~N}$ による $\mathrm{Ga}_{2} \mathrm{O}_{3}$ の還元が不十分となって，結果として $\mathrm{GaN}$ では なく $\mathrm{LiGaO}_{2}$ が得られるものと考えられる。

フラックス法, Czochralski 法においては, まず多結晶 $\mathrm{LiGaO}_{2}$ を合成した後に $1400 \sim 1500^{\circ} \mathrm{C} に て \mathrm{LiGaO}_{2}$ 単結晶成長を行うの に対して，本法は，これらの方法に比べると，常圧でしかも $500 \sim 800^{\circ} \mathrm{C}$ という温和な条件下で直接 $\mathrm{LiGaO}_{2}$ 単結晶を合成で きる点に大きな特徵を有する．これは水熱法の反応温度350～ $400^{\circ} \mathrm{C}$ に比べるとやや高いが, 圧力容器を必要としない点は有 利である。

\section{References}

1) Remeika, J. P. and Ballman, A. A., Appl. Phys. Lett., Vol. 5, pp. 180-181 (1964).

2) Marezio, M., Acta Cryst., Vol. 18, pp. 481-484 (1965).

3) Miller, R. C., Nordland, W. A., Kolb, E. D. and Bond, W. L., J. Appl. Phys., Vol. 41, pp. 3008-3011 (1970).

4) MacKenzie, J. D., Donovan, S. M., Abernathy, C. R., Pearton, S. J., Holloway, P. H., Linares, R., Zavada, J. and Chai, B., J. Electorchem. Soc., Vol. 145, pp. 2581-2585 (1998).

5) Matyi, R. J., Doolittle, W. A. and Brown, A. S., J. Phys. D: Appl. phys., Vol. 32, pp. A61-A64 (1999).

6) Seo, S. W., Lee, K. K., Kang, S., Huang, S., Doolittle, W. A., Jokerst, N. M. and Brown, A. S., Appl. Phys. Lett., Vol. 79, pp. 1372-1374 (2001).

7) Shen, J., Johnston, S., Shang, S. and Anderson, T., J. Cryst. Growth, Vol. 240, pp. 6-13 (2002).

8) Takahashi, H., Fujita, H., Ohta, J., Oshima, M. and Kimura,
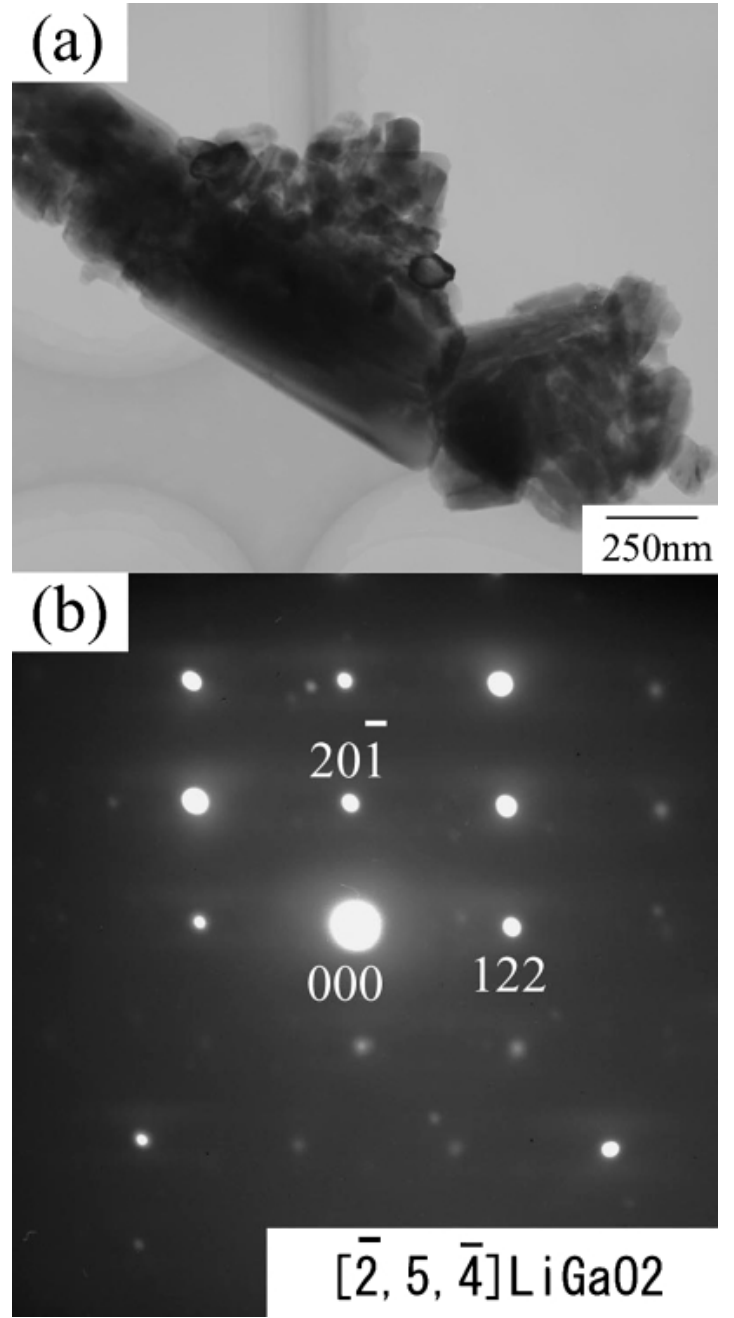

Fig. 9. (a) TEM photograph and (b) the corresponding selected area diffraction pattern of $\mathrm{LiGaO}_{2}$ prepared by a reaction of $\mathrm{Ga}_{2} \mathrm{O}_{3}$ $2 \mathrm{mmol}$ with $\mathrm{Li}_{3} \mathrm{~N} 9.74 \mathrm{mmol}$ in fluxes shown in Table 1 at $600^{\circ} \mathrm{C}$ for $24 \mathrm{~h}$.

M., J. Cryst. Growth, Vol. 259, pp. 36-39 (2003).

9) Kung, P., Saxler, A., Zhang, X., Walker, D., Lavado, R. and Razeghi, M., Appl. Phys. Lett., Vol. 69, pp. 2116-2118 (1996).

10) Amano, H., Sawaki, N. and Akasaki, I., Appl. Phys. Lett., Vol. 48, pp. 353-355 (1986)

11) Nakamura, S., Jpn. J. Appl. Phys., Vol. 30, pp. L1705-L1707 (1991).

12) Lester, S. D., Appl. Phys. Lett., Vol. 66, pp. 1249-1251 (1995).

13) Marshal, D. J. and Laudise, R. A., J. Cryst. Growth, Vol. 1, pp. 88-92 (1967).

14) Kolb, E. D., Capraso, A. J. and Laudise, R. A., J. Cryst. Growth, Vol. 8, pp. 354-358 (1971).

15) Tate, I. and Oishi, S., Nippon Kagaku Kaishi, Vol. 2, pp. 200-203 (1977).

16) Ishii, T., Tazoh, Y. and Miyazawa, S., J. Cryst. Growth, Vol. 186, pp. 409-419 (1998).

17) Saitoh, Y. and Maruyama, T., "Kotai no Ion Dendo," Uchida Rokakuho (1999) [in Japanese].

18) Schönherr, E., Müller, G. and Winckler, E., J. Cryst. Growth, Vol. 43, pp. 469-472 (1978).

19) Mabuchi, A., Iwase, Y., Yasuda, E., Sugiura, T. and Minoura, H., J. Ceram. Soc. Japan, Vol. 113, pp. 291-296 (2005) [in Japanese]. 